\section{Rethinking Civic Education in Tunisia: A Focus on School Curricula and Teacher Training}

Received: August 17, 2019 doi:10.5296/jet.v7i1.15284

\author{
Ezzeddine Saidi (Corresponding author) \\ University of Gabes, Tunisia \\ E-mail: saidiezz@gmail.com
}

Accepted: September 3, 2019 Published: December 5, 2019

URL: http://dx.doi.org/10.5296/jet.v7i1.15284

\begin{abstract}
The paper explores the status of civic education in Tunisian public schools. It calls for seizing the opportunities offered by Tunisia's transition to democracy to improve the teaching and learning of civic education. Before 2011, the Tunisian educational system was not very concerned with raising young generations on the principles and values of civic engagement, participatory citizenship, democratic participation, and social justice. Decision makers did not seem to be aware of the opportunities that young generations may enjoy inside and outside the classroom to learn about these values, and to be more actively committed to other issues, such as human rights, economic development, and the rule of law. However, the Tunisian youth have always used modern technology to keep updated about National and world affairs, and the recent huge developments in the domains of social media and citizen journalism have deepened their awareness about the lack of social justice and human rights in the country. The paper focuses on the importance of civic education in the Tunisian educational system to critically reconsider its potential role in educating the young generations on the values and principles of democracy. This is achieved through a review of two major components of the teaching/learning of civic education, namely how the subject is being taught and how the teachers are being prepared.
\end{abstract}

Keywords: Civic Education, Educational Reform, Teacher Education, Extra-Curricular Activities

\section{Introduction}

In the wake of the revolution, Tunisians found themselves in front of immense challenges to inaugurate a new era in their history that preserves human dignity and builds for a long-lasting democracy. One facet of these challenges is the lack of civic engagement among Tunisians in general, and the youth in particular. Being a fundamental pillar in any well-founded democracy, civic engagement is needed in Tunisia to guarantee the citizens' active involvement in building democratic institutions, respecting the rule of law, and achieving sustainable economic and social development. Making citizens aware of such an important role may require the new 
governments in Tunisia to consider a deep educational reform that trains the new generations on the values and skills of participatory citizenship, a component that has never been the focus of any educational policy adopted by any government in the modern history of Tunisia.

\section{Civic Education in Tunisian School Curricula}

Tunisia needs a new educational policy that prepares young generations to be active participants in a democratic society. This goal is conditioned by reconsidering the mission of education in general and the roles of schools in particular. Duerr et al. (2000) maintain that:

The quest for learning for democratic citizenship changes schools from formative (teaching-based) to constructive and formative (learning-based) educational institutions. The new task is not to impart knowledge and create model behavior in students according to preexisting expert/scientific criteria but to bring about and facilitate learning. School can only manage this task by creating opportunities for personal growth based on the respect for individuality and dignity" (2000, p. 42).

To build a constructive and formative educational system, the new educational policy will need to revise the old curricula that strive to equip students with subject-matter knowledge in sciences, arts, and humanities, and give the least importance to civic education and citizenship. A telling example on that can be found in the teaching of a subject called "civic education" to secondary school students. The subject not only has the lowest coefficient among all other subjects taught in secondary education but is also taught in a weekly one-hour session while some other subjects are taught from three to five hours per week. Such a low status given to the subject in a timetable that may include 34 to 38 hours per week testifies to the very limited importance given to civics and civic education in the current Tunisian public educational system.

To improve the status of civic education in Tunisian school curricula, educational decision makers may need to adopt a holistic and coherent approach to the teaching of civics that does not limit teaching/learning to the weekly one-hour contact, an approach that puts knowledge, attitudes, and values of democratic participation into real practice inside and outside school. To do so, civic education may be also taught in extra-curricular activities that aim to deepen students' understanding of social responsibility and democratic participation (cf. Bailey, 2000; Edwards \& Fogelman, 1993; McCowan, 2009; Patrick, 1999).

Birzea (2000) maintains that such activities should aim at "making young people... better equipped to participate actively in democratic life by assuming and exercising their rights and responsibilities in society" (2000, p. 18). Examples of these activities may include:

- Visiting local and regional institutions, government agencies, and nongovernmental organizations (NGOs) to learn about the different ways a citizen can be an active agent for change and a participant member in a developing community.

- Organizing curricular and extracurricular activities at school that train students on processes of political participation and prepare them to be actively involved in political life. Examples of these activities include the organization of mock elections and simulations of local and regional councils where students play the role of decision 


\section{Macrothink}

Journal of Education and Training

ISSN 2330-9709

2019, Vol.7, No.1

makers.

- Enhancing field research by engaging students in learning tasks involving the collection of data from different sources in local and regional communities to deepen their understanding of the social and economic needs and the priorities of these communities.

- Training students on voluntary and charity work by helping them establish contact with local and regional organizations and be active members in them. In this type of activities, teachers may need to be themselves committed to some sort of social work to make students follow them as role-models.

- Carrying out project work requiring students to adopt a cooperative learning process to produce a coherent piece of research. This type of activity can be most effective when it focuses on local, regional, or national political, social and economic issues. In addition to the fact that it helps learners acquire a deep understanding of the issues in focus, this activity makes them enjoy a collaborative learning process that they may not always enjoy in their ordinary classes.

- Strengthening ties of collaboration with other schools in other parts of the country (or even abroad) to exchange experiences and success stories with other students. This activity is constructive because it introduces learners to the merits of difference and diversity and makes them learn from one another regardless of the many differences they may have.

- Creating school councils where students are engaged in real democratic participation. These councils will follow rules similar to those adopted in national elections where candidates run for office by advocating electoral programs and working to implement them during their mandates.

In addition to the fact that these activities introduce learners to, and train them on, principles of civic engagement, they make civic education more than a mere encounter between a teacher and her/his students to talk about some theoretical issues thought to introduce students to the different ways they can be civically committed to the well-being of their communities and society. These activities are likely to make civic education a real social act that students can perform inside and outside school to be active agents of positive development and change.

\section{Civic Education in Tunisian Teacher Education}

Including the types of activities mentioned above in the curriculum will require training teachers on teaching methods that do not restrict teacher-student interaction to the classroom. Teachers may seek opportunities for professional development in innovative pedagogy that is different from the current training approach adopted in most Tunisian public schools.

In Tunisia, all newly-recruited secondary school teachers attend the same training program. The program is made up of a pre-service phase and an in-service phase that usually ends in recruiting the trainee for a life-long career in public education. This training method is adopted for the teachers of all subjects across the country. The major features of the training methods 


\section{Macrothink}

Journal of Education and Training

ISSN 2330-9709

2019, Vol.7, No.1

adopted in the two phases of the program can be summed up in the following points (cf. Saidi, 2012):

- The training methods adopted are more conform to the micro-approach to teacher education, an approach restricting effective teacher preparation to the teacher's acquisition of a good repertoire of observable low-inference skills and techniques thought to guarantee her/his success in her/his job.

- The trainee undergoes an evaluation at the end of the in-service phase to determine whether she/he is going to be recruited for a life-long career or not. The evaluator is the inspector of the subject being taught.

- The inspector also supervises most training sessions and workshops that the trainee attends, which means that the professional development plan the teacher will follow is largely determined by the inspector.

- The fact that the inspector is a hiring-firing authority usually makes novice teachers adopt a teaching method strictly guided by the recommendations and guidelines received from the inspector during the two phases of the training program. This fact may make novice teachers more concerned with pleasing the inspector than with being innovative in their job.

Linking these features of teacher education to the list of activities thought to improve the status of civic education in Tunisian curricula, it becomes clear that Tunisian teachers may lack the necessary training to get advantage of all curricular and extra-curricular opportunities to include a civic education component in their teaching. The training that they receive does not encourage them to be innovative and extend their work to outside the classroom, which may make them continually inclined to adopt a traditional teaching method that restricts their interaction with students to the classroom.

Reviewing the teaching of civic education in Tunisia, therefore, requires a revision of teacher education as well. The new training approach that would improve the teachers' willingness and readiness to work on curricular and extracurricular activities that are likely to improve the status of civic education in Tunisia would need to care about the following points:

- Teacher training needs to conform more to the macro-approach that allows the teacher to adopt a self-sustained professional development plan. This approach will reduce the teacher's dependence on the opinions of the inspector and will allow her/him to try out innovative teaching methods away from the very judgmental eyes of the inspector of the subject.

- Including a training component on how to establish and maintain contact with institutions, associations, organizations, and civil society in general to seek ways of mutual collaboration to make students enjoy learning while being committed to different forms of civic work.

- Encouraging teachers to collaborate and adopt extra-curricular activities that are 


\section{Macrothink Mnstitutem}

likely to engage their students in a cooperative learning process. Such activities will make students enjoy learning while discovering the merits of social collaboration.

- Training teachers on how to enjoy teaching away from the unique traditional classroom setting by introducing them to techniques of supervising school clubs and associations which can serve as suitable spaces to teach students how to be more civically engaged.

These training activities are likely to prepare teachers to be more able to include civic education activities in their teaching. They will allow them to view teaching from a different perspective, namely as a vehicle for civic commitment, and make them more open to a teaching methodology that establishes links between course content, students' needs, and the immediate context where the act of teaching takes place.

\section{Conclusion}

Tunisia is going through a difficult transition phase, the major outcome of which will highly depend on the degree of civic commitment that its citizens will display. Such commitment will in its turn depend on the amount of work to be done to sensitize and train citizens, and especially the youth, on the merits and ways of being actively involved in civic work.

Reconsidering the status of civic education in the Tunisian educational system by integrating innovative ideas in the official curricula and teacher training programs seem to offer unlimited opportunities to develop the youth's awareness about the importance of their adherence to civic work. Differently from many other countries in the region, mainly those rich in natural resources, Tunisia has always relied on its human resources to face all sorts of challenges. In such a post-revolutionary scene, one of the major challenges facing the newly-born democracy seems to be enhancing the youth's energy to work for the common good. One of the shortest ways to do that is through investment in education, namely in improving the status of civics in the national educational systems.

\section{References}

Bailey, R. (Eds.). (2000). Teaching Values and Citizenship across the Curriculum. London: Kogan Page Limited.

Birzea, C. (2000). Education for Democratic Citizenship: A Lifelong Learning Perspective. Strasbourg: Council for Cultural Co-operation.

Duerr, K., Spajic-Varkas, V., \& Martins, I. F. (2000). Strategies for Learning Democratic Citizenship. Council of Europe.

Edwards, J., \& Fogelman, K. (Eds.). (1993). Developing Citizenship in the Curriculum. London: David Fulton Publishers.

McCowan, T. (2009). Rethinking Citizenship Education: A Curriculum for Participatory Education. London: Continuum International Publishing Group.

Patrick, J. (1999). Education for constructive engagement of citizens in democratic civil society. In C. Bahmueller, \& J. Patrick (Eds), Principles and Practices for Democratic Citizenship. 


\section{Macrothink

Bloomington. IN: ERIC Clearinghouse.

Saidi, E. (2012). Evaluation of Tunisian EFL Teachers'Pre- and In-service training: Exploring the Form and Content of Teacher Development and its Impact on Classroom Practice. Unpublished $\mathrm{PhD}$ Dissertation: Higher Institute of Languages, University of Carthage, Tunisia.

\section{Copyright Disclaimer}

Copyright reserved by the author(s).

This article is an open-access article distributed under the terms and conditions of the Creative Commons Attribution license (http://creativecommons.org/licenses/by/3.0/). 